\title{
BIM for Lean Building Surveying Services
}

\author{
Ali Mahmood, Sepehr Abrishami
}

\begin{abstract}
Purpose - The aim of this study is to determine whether the implementation of BIM concepts of the various processes involved in building surveying practice can lead to a reduction in waste. In turn leading to a synergy between BIM functionalities and lean production concepts.

Design/methodology/approach - To verify and validate the existence of this synergy between the two methods in building surveying, evidences were gathered from previous literature that supports these interactions. Next, a questionnaire was conducted for the purpose of identifying new interactions as well as providing further evidence to support existing interactions. Finally, based on the findings from previous literature and the results of the questionnaire, an interaction matrix was constructed linking the two concepts with the relevant evidence found.

Findings - The results of the questionnaire show that the BIM functionality with the highest interactions, maintenance of information integrity, had a high correlation with the reduction of variability, cycle time, batch size, and promoting standardization of value flow. 4D model-based scheduling, the second highest functionality, showed a high correlation with the reduction of variability, cycle time, batch size as well as an increase in the use of visual management. Finally, the results of the interaction matrix between the two concepts showed that the BIM functionalities with the most interactions were maintenance of information integrity, visualisation of form, and the automated generation of models and documents. The lean principles with the most interactions were reducing variability, cycle time, batch size as well as 'enables visual management'. While most of these interactions were positive, negative interactions were also observed. These negative interactions were due to the fact that the level of competency and knowledge in BIM for building surveyors is at reduced levels which can lead to increased human errors.

Originality/value - The significance of this study is to provide the basis for building surveying organisations who wish to implement BIM and how this would lead to a synergy between BIM functionalities and lean principles. Both positive and negative interactions were considered to provide these organizations with different options for waste elimination.
\end{abstract}

Keywords building surveying, building information modelling, BIM, lean construction, BIM for existing buildings, BIM for small practices

Paper type Research paper

\section{Introduction}

With the current effort made by the United Kingdom government to reduce waste in time and cost generated from various activities in the architecture, engineering, construction and operation industry (AECO) (Office, 2011), there has been a rise in the past few years in the use of new digital technologies which has shifted the industry to meet with the demands of waste reduction. Building Information Modelling (BIM), is one of these digital technologies that have seen an increased use in the industry. The Royal Institute of Charted Surveyors (RICS) released a professional guidance mandating the use of level-2 BIM, which includes collaborative working and requires an information exchange process that is unique to each project for a government led projects (Royal Institution of Chartered Surveyors (RICS), 2016). BIM functionalities in the design, construction, and operational and management phases of a construction project have, in theory, proven to reduce construction variability (Akinade et al., 2018; Jeong et al., 2016). Lean thinking on the other hand, is a philosophy that is derived from the concepts and principles of lean production, which was first introduced to the manufacturing system of Toyota car production. These concepts aim to eliminate waste in production and promote the value (Sarhan et al., 2018; Sarhan and Fox, 2013).

With the emergence of both the BIM and lean thinking in the industry, extensive research has been conducted in order to find synergies between the BIM functionalities and lean thinking principles at the various stages of the construction lifecycle (Koseoglu and Nurtan-Gunes, 2018; de Mattos Nascimento et al., 2017). The findings highlighted the importance of emerging technologies in enhancing the value and eliminating waste through the promotion of lean concepts such as Muda (Rajendran and Pathrose, 2012; Won et al., 2016), and Mura (Nath et al., 2015). In service oriented systems such as building surveying, Al Hattab and Hamzeh (2018) and Hochscheid and Halin (2019) argued that BIM can be used as a lean tool to reconfigure the structure and communication in an organization for the purpose of improving the quality of services by managing errors and restricting their occurrence.

The aim of this study is to investigate the existence of synergy between the two methods with regards to the building surveying practices by providing evidence from both previous literature and a questionnaire to verify and validate this existence. For this purpose, BIM functionalities and lean principles were extracted from literature based on their relevance to the building surveying practices. Next, evidence linking the two concepts was gathered from previous literature. These evidences were further expanded by utilizing a questionnaire to determine new evidence and to verify and validate existing ones. Finally, the BIM functionalities and lean thinking principles were organised in an interaction matrix using the evidence found to link the two theories. 


\section{Theoretical Background}

\subsection{Building surveying}

The role of a building surveyor is to provide clients with an expert and impartial assessment of defects, repairs, and maintenance options. The aim of the services provided by the building surveyor is to help the clients make an informed decision regarding refurbishments or purchase of property (RICS, 2012). Building surveying suffers from several issues that may hinder the quality of service provided to the client. One of these issues is the increased number of documentations of information needed for effective reporting. Most of these information are stored in paper documentation form which can be difficult to access after a period of time (Liao et al., 2020). Moreover, inconsistent reporting of defects, which is another common issue with building surveyors, can lead to problems regarding purchasing and effective decision making (Jusselme et al., 2020). The practice also lags in-terms of technology, making communication with other stakeholders in a project difficult to achieve and prone to errors (Ali and Woon, 2013; Tauriainen et al., 2016).

\subsection{Building Information Modelling (BIM)}

BIM models are characterized by parametric objects, which represent physical building elements, that carry computable graphic and data attributes that identify them to software applications, as well as parametric rules that allow them to be manipulated in an intelligent fashion (Eastman et al., 2018; Volk et al., 2014). These objects should consist of geometric definitions and associated data rules, the geometry is integrated none redundantly, and the parametric rules should automatically modify associated geometries when inserted into a building model or when changes are applied to associated objects (Yin et al., 2020). Moreover, objects can be defined at hierarchy levels, the rules of the objects must automatically identify if a change to an object is feasible, and the objects must have the ability to link to or send and receive attributes (Kong et al., 2020). To implement BIM on a macro level, market \& industry level, Succar et al., (2012) stated that there must be a sufficient foundational framework suitable for the systematic investigation of the BIM domain. This framework comprises of three main parts: BIM fields of activity, BIM stages delineating implementation maturity levels, and BIM lenses providing the depth of enquiry necessary to identify, asses, and qualify BIM fields and stages. Once BIM is integrated into a practice, users must conduct an evaluation of the BIM maturity level (Wu et al., 2017). The macro maturity model as developed by Succar and Kassem (2015) is one the widely used models for the purpose of assessing the BIM maturity level (Alan et al., 2017).

\subsection{BIM and building surveying}

The uses of BIM in building surveying can range from as-built rendering, historical documentation, maintenance, monitoring and assessment, as well as retrofit planning (Ghaffarianhoseini et al., 2017). An emerging BIM technology that can be utilized in building surveying practices, is the scan to BIM technology (Guo et al., 2020; Tzedaki and Kamara, 2013). This technology involves the 3D scanning of a property's space to create as-built 3D BIM models (Ilter and Ergen, 2015; Son et al., 2015). The process involved in this technology aims to increase the measurement precision of a property (Bonduel et al., 2017; Mahdjoubi et al., 2013). Moreover, this technology provides a better visualization of spaces in a virtual environment (Layek et al., 2020). However, the current software packages require significant human input, increasing the risk of inefficiency due to human error (Son et al., 2015). In addition the increased human input may lead to an underestimation of a BIM object's information accuracy (Bonduel et al., 2017). Lack of a clear framework that can dictate the integration of BIM into the building surveying practice is another challenge that hinders the implementation of BIM into practice (Aibinu and Venkatesh, 2014; Brumana et al., 2020; Rocha et al., 2020).

\subsection{Lean thinking theory in service-oriented systems}

Lean thinking is an approach to management that focus on waste reduction while maintaining the quality of the product (Wilson, 2010). In the AEOC industry, lean construction applies to the various processes involved. Lean construction can be defined as the application of the principles and concepts of the Toyota Production System (TPS) for the purpose of enhancing the design and construction value and reducing waste in resources (Mano et al., 2019). Pearce and Pons (2013) and Nicholson and Pakgohar (2020) argued that lean thinking can be implemented within an organization without the need for a substantial investment in training. Regarding the implementation of the lean concepts into a service system, Liker and Morgan (2006)suggested that the lean principles should focus on the philosophy, process, people and partners, as well as problem solving aspects associated with an organization. Thus, lean implementation is a continuous improvement process that needs to be assessed over time (Vilar and Santos, 2020). To implement lean thinking into a service-based production system, Womack and Jones (2003) suggested the starting point in the implementation is to identify 'value' from a customer's viewpoint, followed by sequencing the processes to generate that value, and finally strategizing the flow of that value. The lean management further expands on this approach by adding 5 step process, identify customer value, map value stream, flow, establish pull, and perfection (Abdallah et al., 2019; Czifra et al., 2019). 
'Muda' or waste in lean theory can be categorized into two different types. The first type, Type 1 Muda, refers to activities that add no value to the process, but are necessary due to the current technology (Bauer, 2016). Type 2 Muda refers to any type of waste that reduces the value for any stakeholder and is a priority in elimination (Lodgaard et al., 2016; Maid and Desai, 2019). Bicheno and Holweg (2016) proposed an equation that provides an illustration of how waste is generated. In this formula, demand is defined as the amount of work in the system. It's made up of two types of demands, the true demand and the failure demand, which are generated from rework resulting from failure to meet the true demand in the first time. Capacity is defined as the resources allocated to achieve the demand or it can also be defined as work plus waste. The result from deducing demand and capacity is a gap. Once demand exceeds there is an over-load or Muri. If demand is less than capacity, then there is an underload. Reducing the gap between demand and capacity can lead to improving the customer service or meeting customer demand.

Given that the building surveying is a service-oriented production system, the research focused mainly on the waste generated in service-oriented systems as identified in the literature. Waste in service-oriented production systems are defined as either a delay, a duplication, an unnecessary movement (Bicheno and Holweg, 2016), an unclear communication, incorrect inventory (Jing et al., 2020), opportunity lost and errors (Zirar et al., 2020). Delay in customer service refers to the variability in wait time for delivery as well as the variability in perceiving the length of wait time, along with any issues that can arise due to this variability (Bicheno and Holweg, 2016; Silva et al., 2020). Duplication refers to re-entering data, repeating the details on forms, copying information across or answering queries generated from several sources within the same organisation (Bicheno, 2016). Unnecessary movement can be generated from queuing several times, lack of one-stop or poor ergonomics in the service encounter. Unclear communication can be generated due to confusion over product or service leading the customer to seeking clarification which, in turn, can lead to misuse or duplication (Lai et al., 2019)

The next type of waste in customer service is incorrect inventory. This can be generated due to out of stock, not getting the product exactly as required by the customer or getting an alternative product or service that may be inferior to the customer's requirements. Opportunity lost refers to the attitude of the producers towards the customer which can lead to either retaining or losing the customer (Rudnick et al., 2020). Finally, errors refer to the errors found in service transaction, product defects or inferior products (Banawi and Bilec, 2014).

\section{Methodology}

To achieve the aim of this research, the study utilised a mixed approach which consisted of both literature review and a questionnaire. Andujar-Montoya et al. (2019) recommended that a comprehensive literature review can be utilized for the purpose of identifying BIM functionalities and lean thinking principles that can be deemed as relevant to the practices of building surveying. Possible synergies between the two principles in the building surveying practice can be uncovered from previous literature (Elmaraghy et al., 2018). Hence, interactions between BIM functionalities and lean thinking principles are hypothesized based on the findings from previous literature for the purpose of uncovering evidence, as shown in Figure 1. To validate these hypothesized interactions, a questionnaire containing both open and close ended questions was designed for this purpose (Pitti et al., 2019). The close ended questions embedded statements that contain evidence of this interaction. The responses for these statements were a varying degree of agreement or disagreement based on a five-point Likert scale where 1 = strongly disagree, 2 = agree, 3 = neutral, $4=$ disagree, $5=$ strongly agree.

The second part of the questionnaire contains open ended questions which can lead to the unstructured data collection. A separate coding analysis will be performed to determine the frequencies of the themes measured as well as a rating for each of these categories. The ratings used to measure each category is based on a range of a negative two for a strongly negative rating, and a positive two for a strong positive rating (Sapsford and Jupp, 2006).

The next logical step in this research is constructing an interaction matrix that attempted to link the BIM functionalities to the lean thinking principles. The reasoning behind each interaction between BIM functionalities and lean principles will be justified through evidence collected from the previous works of literature as well as the data gathered from the questionnaire. 


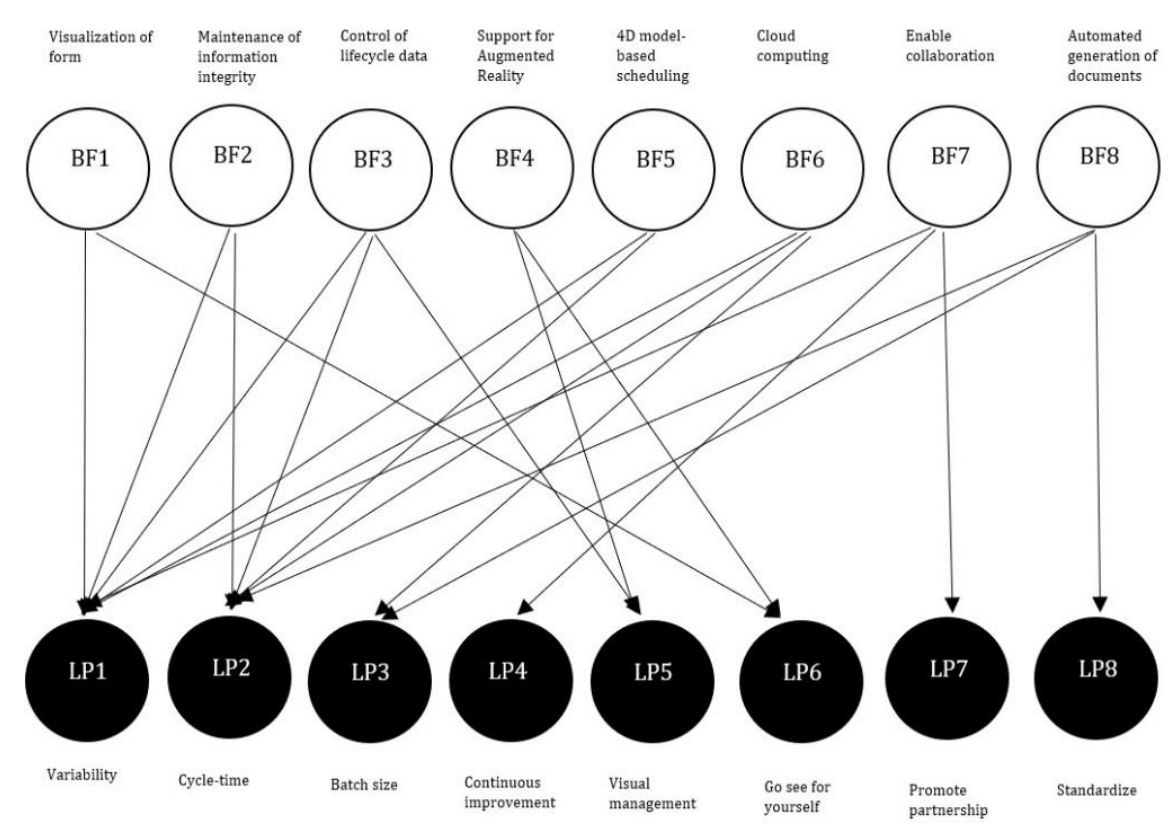

Figure 1. Theoretical model constructs

\section{Relevant BIM functionalities}

The aim of this section was to identify the relevant BIM functionalities that can be linked to lean production principles which can lead to improvements in the flow and value of the end product. This was achieved by gathering data from previous works of literature that touch on the subject of BIM and BIM functionalities. Table 1 shows the relevant BIM functionalities along with an explanation as to why each functionality is relevant to building surveying.

\begin{tabular}{ll}
\hline Functionality & Evidence supporting selection of \\
& functionality from literature \\
\hline Visualization of form & 1. BIM enabled software allow their \\
users to observe a 3D rendered & version of the end-product of the \\
& design. As the data are available in \\
& 3D, the concept of BIM allows for the \\
use of real-time visualizations as a & tool to communicate ideas and \\
sharing information between the & different stakeholders \\
& 2. Visualization of form allows the \\
& different stakeholders to evaluate the \\
& different aspects of the design \\
& efficiently, including cost-estimation, \\
energy analysis and production & planning \\
3. Clients can utilize this functionality \\
to organize and connect the large \\
amounts of data associated with each \\
project \\
\\
1. Utilizing Industry Foundation \\
Classes (IFC) models, a model with \\
neutral formats, allows for seamless \\
exchange of data between the \\
stakeholders as well as maintaining \\
consistency of the information \\
shared. \\
2. Information is stored in one \\
location, BIM users have the ability to \\
store their relevant information in an \\
integrated cloud platform designated \\
for that project, as opposed to CAD \\
drawings where multiple versions of \\
the model is stored in various \\
locations. \\
3. Design clashes can be avoided \\
\end{tabular}

(Johansson et al., 2015)

(Hardin and Mccool, 2015)

(Lee, Eastman, et al., 2018)

(Ghaffarianhoseini et al., 2017; Zhang, Seet, et al., 2015)

(Akponeware and Adamu, 2017) 
Controlling lifecycle cost data

Support for augmented reality

4D model-based scheduling

Cloud computing technology

Collaboration

Coordination

Evaluating property data in real-time through the coordination of design in a 3D design and decision-making environment

1. A BIM enabled software allow its users to effectively control the holding lifecycle of a property through storing information and providing convenient access to this information to all stakeholders

2. Early design coordination between the stakeholders can allow for effective value engineering and cost estimation. This would lead to a reduction in uncertainty in costs.

Augmented reality integration within a project can aid the surveyor in providing the client with an efficient report of deficiencies. Moreover, BIMbased AR systems have the ability to display scheduling information. This functionality would allow clients to make informed decisions

This functionality allows its users for a more accurate prediction of daily, weekly and monthly activities, which can lead to a reduction of waste due to the uncertainty generated by the interdependencies and overlapping of activities

1. Giving access to various stakeholders for the purpose of editing and storing relevant information can allow for improved collaboration and effective decision making throughout the project lifecycle.

2. Cloud-based BIM models have the ability to track and monitor project progress in real-time. This can lead to effective decision-making by the various stakeholders to meet project deliverables

Collaboration allows stakeholders to share their mistakes as learning opportunities. Moreover, trust and long-term relationships are encouraged in a BIM oriented project due to the involvement of the various stakeholders in the design and decision-making process

In a BIM oriented project, coordination between the stakeholders at the various stages of the project lifecycle can lead to a reduction in uncertainty, delivering a more predictable path towards the expected quality of the end-product

Storing of real-time data with regards to building parameters such as structural stability, timing, energy and space performance can allow for more accurate reporting by the building surveyor. Moreover, this allows for a detailed maintenance history of the property.
(Oskouie et al., 2012)

(Forgues et al., n.d.)

(Meža et al., 2014; Teicholz, 2013)

(Hardin and Mccool, 2015; Lee et al., 2020)

(Oliver et al., 2020; Teicholz, 2013)

(Han and Golparvar-Fard, 2015; Mahdjoubi et al., 2013; Matthews et al., 2015)

(Lee, Chong, et al., 2018; Oraee et al., 2017)

(Park and Lee, 2017; Yarmohammadi and Ashuri, 2015)

(Patacas et al., 2015; Zhang, Seet, et al., 2015)

(Deng et al., 


\section{Lean theory principles}

Lean principles provide the required techniques for implementing lean theory in a production system. They allow for optimization, continuous improvement, elimination of waste and a focus on delivering the required quality desired by customers (Oskouie et al., 2012). There are several lean principles that are found in literature (Liker and Morgan, 2006), (Bicheno and Holweg, 2016), and (Womack and Jones, 2003). Table II Compiled the most relevant lean concepts that can be associated with building surveying that could contribute to the continuous improvement in two key lean theory concepts value and flow (Zhang et al., 2020). Each principle in the table below contains a common definition and evidence from the literature to support the selection.

\begin{tabular}{|c|c|c|c|}
\hline Lean principle & Definition & $\begin{array}{l}\text { Evidence } \\
\text { supporting } \\
\text { selection }\end{array}$ & Source \\
\hline Variability & $\begin{array}{l}\text { Refers to the } \\
\text { fluctuations and } \\
\text { unforeseen } \\
\text { conditions that } \\
\text { render the } \\
\text { objectives of a } \\
\text { process to be } \\
\text { unstable and } \\
\text { obscure }\end{array}$ & $\begin{array}{l}\text { Lean production } \\
\text { concepts aim to } \\
\text { reduce the } \\
\text { variability in a } \\
\text { process through } \\
\text { focusing on } \\
\text { quantity } \\
\text { control, full } \\
\text { integration, } \\
\text { continuous } \\
\text { evolution, and } \\
\text { consistent } \\
\text { management }\end{array}$ & $\begin{array}{l}\text { (Issa, 2013; Sacks et al., 2010; Thomas et al., } \\
\text { 2002; Zhang et al., 2020) }\end{array}$ \\
\hline Cycle time & $\begin{array}{l}\text { Refers to the } \\
\text { total time taken } \\
\text { to complete the } \\
\text { processes } \\
\text { involved in } \\
\text { production. This } \\
\text { principle can be } \\
\text { used as an } \\
\text { indicator to } \\
\text { measure } \\
\text { performance } \\
\text { and promote } \\
\text { continuous } \\
\text { improvement }\end{array}$ & $\begin{array}{l}\text { A reduction in } \\
\text { cycle-time can } \\
\text { lead to savings } \\
\text { in terms of costs } \\
\text { and time, thus } \\
\text { cycle-time is } \\
\text { correlated with } \\
\text { variability }\end{array}$ & $\begin{array}{l}\text { (Bamana et al., 2019; Czifra et al., 2019; } \\
\text { Goienetxea Uriarte et al., 2020; Sacks et al., } \\
\text { 2010) }\end{array}$ \\
\hline Batch size & $\begin{array}{l}\text { Refers to the } \\
\text { overloading of } \\
\text { resources. It can } \\
\text { be associated } \\
\text { with 'Murri'3. } \\
\text { Batches can be } \\
\text { defined as a set } \\
\text { of tasks } \\
\text { performed in } \\
\text { distinct spaces }\end{array}$ & $\begin{array}{l}\text { In lean } \\
\text { production, the } \\
\text { aim of this } \\
\text { principle is to } \\
\text { effectively } \\
\text { control the } \\
\text { quantity of the } \\
\text { output to } \\
\text { reduce the } \\
\text { cycle-time due } \\
\text { to batching }\end{array}$ & $\begin{array}{l}\text { (Herrera et al., 2019; Sacks et al., 2010; Sacks } \\
\text { and Goldin, 2007) }\end{array}$ \\
\hline $\begin{array}{l}\text { Promoting } \\
\text { continuous } \\
\text { improvement }\end{array}$ & $\begin{array}{l}\text { Also known as } \\
\text { Kaizen, refers to } \\
\text { the } \\
\text { methodology of } \\
\text { processes that } \\
\text { are aimed at } \\
\text { improving the } \\
\text { flow of working } \\
\text { conditions } \\
\text { through the } \\
\text { elimination of } \\
\text { problems and } \\
\text { waste }\end{array}$ & $\begin{array}{l}\text { In a lean } \\
\text { organization } \\
\text { learning from } \\
\text { action is } \\
\text { encouraged and } \\
\text { learning can be } \\
\text { achieved } \\
\text { through } \\
\text { implementing a } \\
\text { feedback } \\
\text { system on the } \\
\text { level of work } \\
\text { satisfactory thus } \\
\text { mistakes are } \\
\text { seen as }\end{array}$ & $\begin{array}{l}\text { (Aziz and Hafez, 2013; Belhadi et al., 2020; } \\
\text { Bicheno and Holweg, 2016; Dombrowski and } \\
\text { Mielke, 2013; Oskouie et al., 2012) }\end{array}$ \\
\hline
\end{tabular}




\begin{tabular}{|c|c|c|c|}
\hline & & $\begin{array}{l}\text { opportunities to } \\
\text { improve and not } \\
\text { something to be } \\
\text { punished for }\end{array}$ & \\
\hline Standardization & $\begin{array}{l}\text { Reduction of } \\
\text { variability in } \\
\text { both temporal } \\
\text { and product } \\
\text { features }\end{array}$ & $\begin{array}{l}\text { Standardization } \\
\text { correlates with } \\
\text { other principles } \\
\text { such as } \\
\text { continuous } \\
\text { improvement }\end{array}$ & $\begin{array}{l}\text { (Bashir et al., 2013; Esquenazi and Sacks, } \\
\text { 2006; Sacks et al., 2010) }\end{array}$ \\
\hline Visuality & $\begin{array}{l}\text { Refers to the } \\
\text { visual } \\
\text { management of } \\
\text { operations. This } \\
\text { is done by } \\
\text { simplifying and } \\
\text { standardizing } \\
\text { the processes } \\
\text { involved }\end{array}$ & $\begin{array}{l}\text { This principle } \\
\text { aims at } \\
\text { identifying } \\
\text { whether the } \\
\text { operations or } \\
\text { schedules are } \\
\text { on the target } \\
\text { path or have } \\
\text { been diverted } \\
\text { from it }\end{array}$ & $\begin{array}{l}\text { (Alhuraish et al., 2016; Bicheno and Holweg, } \\
\text { 2016) }\end{array}$ \\
\hline $\begin{array}{l}\text { Go and see for } \\
\text { yourself }\end{array}$ & $\begin{array}{l}\text { Refers to } \\
\text { managing the } \\
\text { production } \\
\text { system by direct } \\
\text { observation } \\
\text { instead of } \\
\text { reports and } \\
\text { hearsay. Lean } \\
\text { implementation } \\
\text { takes place on } \\
\text { site and not in } \\
\text { the office }\end{array}$ & $\begin{array}{l}\text { Issues in a } \\
\text { place where } \\
\text { value is created } \\
\text { are often } \\
\text { visible. To } \\
\text { eliminate these } \\
\text { issues from } \\
\text { arising, } \\
\text { management is } \\
\text { encouraged to } \\
\text { observe the } \\
\text { state of a } \\
\text { process in } \\
\text { person }\end{array}$ & $\begin{array}{l}\text { (Bicheno, 2016; Dombrowski and Mielke, } \\
\text { 2013; Pamfilie et al., 2012) }\end{array}$ \\
\hline Partnership & $\begin{array}{l}\text { Is a lean } \\
\text { principle which } \\
\text { states that each } \\
\text { member } \\
\text { involved in a } \\
\text { system is able to } \\
\text { add value. This } \\
\text { would lead the } \\
\text { different } \\
\text { participants to } \\
\text { share } \\
\text { responsibilities } \\
\text { for success and } \\
\text { failure }\end{array}$ & $\begin{array}{l}\text { Increasing } \\
\text { participation } \\
\text { leads to } \\
\text { increased trust } \\
\text { between the } \\
\text { different } \\
\text { stakeholders } \\
\text { which leads to } \\
\text { a reduction in } \\
\text { waste in time } \\
\text { and improves } \\
\text { quality through } \\
\text { the creation of } \\
\text { shared value }\end{array}$ & $\begin{array}{l}\text { (Andelin et al., 2015; } \\
\text { Bicheno and Holweg, } \\
\text { 2016; Iyer et al., } \\
\text { 2019; Lehr et al., } \\
\text { 2019) }\end{array}$ \\
\hline
\end{tabular}

\section{Questionnaire Results \& Analysis}

The data collected from the questionnaire were analysed using IBM SPSS 24. The respondent's profile in terms of years of experience, organization size, and BIM implementation are shown in Tables I, II, and III, respectively.

\begin{tabular}{llllr}
\hline Years of Experience & Frequency & Percent & Valid Percent & $\begin{array}{l}\text { Cumulative } \\
\text { Percent }\end{array}$ \\
\hline Under 2 years & 11 & 52.4 & 52.4 & 52.4 \\
2 to 5 years & 2 & 9.5 & 9.5 & 61.9 \\
6 to 10 years & 4 & 19.0 & 19.0 & 81.0 \\
11 to 15 years & 1 & 4.8 & 4.8 & 85.7 \\
16+ years & 3 & 14.3 & 14.3 & Table III. Respondent's \\
\hline
\end{tabular}

\begin{tabular}{ccccc}
\hline Organization size & Frequency & Percent & Valid Percent & Cumulative percent \\
\hline 0 to 50 & 10 & 47.6 & 47.6 & 47.6 \\
51 to 100 & 1 & 4.8 & 4.8 & 52.4 \\
101 to 200 & 1 & 4.8 & 4.8 & 57.1
\end{tabular}

Table IV.

Respondent's profile 


\begin{tabular}{|c|c|c|c|c|c|}
\hline $\begin{array}{c}201 \text { to } 499 \\
500+ \\
\end{array}$ & $\begin{array}{l}1 \\
8 \\
\end{array}$ & $\begin{array}{r}4.8 \\
38.1 \\
\end{array}$ & $\begin{array}{c}4.8 \\
38.1 \\
\end{array}$ & $\begin{array}{c}61.9 \\
100.0 \\
\end{array}$ & - organization size \\
\hline $\begin{array}{c}\text { BIM } \\
\text { implemented? }\end{array}$ & Frequency & Percent & Valid Percent & $\begin{array}{l}\text { Cumulative } \\
\text { Percent }\end{array}$ & \\
\hline Yes & 10 & 47.6 & 47.6 & 47.6 & \\
\hline No & 11 & 52.6 & 52.6 & 100.0 & $\begin{array}{r}\text { Table V. } \\
\text { Respondent's profile } \\
- \text { BIM } \\
\text { implementation }\end{array}$ \\
\hline
\end{tabular}

6.1 Construct model reliability

A Cronbach analysis was conducted to test the reliability of the initial interactions structural model proposed in Figure 1 by testing the adequacy between each inter-item subscale (Tavakol and Dennick, 2011). The results of this analysis are shown in Table IIII. From this analysis, it was found that for 'reducing variability' subscale, the inter-items measured (visualization of form, maintenance of information integrity, controlling life cycle data, 4D model-based scheduling, and collaboration) showed a Cronbach alpha value of. 689. For this subscale, it was shown that the reliability between the inter-items measured can increase to .797 by removing the 'visualization of form' item.

'Maintenance of Information integrity', 'controlling life-cycle data', '4D model based scheduling and automated generation of models and documents' inter-items showed an adequate level of inter-item reliability with a Cronbach alpha of .854 for the subscale 'reducing cycle-time'. Third, 4D model-based scheduling, automated generation of models and documents, maintenance of information integrity and collaboration had high values of Cronbach alpha of.859 for the subscale 'reducing batch size'.

Another subscale measured in this analysis is 'use of visual management'. The inter-items were 'controlling life cycle data', '4D model-based scheduling', 'automated generation of models and documents' and 'support for augmented reality'. The Cronbach alpha value was found to be .810 . Lastly, automated generation of models and documents and maintenance of information integrity inter-item had a very high level of measurement reliability of .930 on the Cronbach alpha for the subscale 'standardize'.

\begin{tabular}{|c|c|c|c|}
\hline Subscale & Inter-item & $\begin{array}{l}\text { Cronbach } \\
\text { Alpha Value }\end{array}$ & \\
\hline $\begin{array}{c}\text { LP1- } \\
\text { Variability }\end{array}$ & $\begin{array}{ll}- & \text { BF1- Visualization of form } \\
- & \text { BF2- Maintenance of information } \\
\text { integrity } \\
\text { - } & \text { BF3- Controlling life cycle data } \\
\text { - } & \text { BF5-4D model-based scheduling } \\
\text { - } & \text { BF7- Collaboration }\end{array}$ & 689 & \\
\hline $\begin{array}{l}\text { LP2- Cycle } \\
\text { time }\end{array}$ & $\begin{array}{l}\text { - } \quad \text { BF2- Maintenance of information } \\
\text { integrity } \\
\text { - } \quad \text { BF3- Controlling life cycle data } \\
\text { - } \quad \text { BF5-4D model-based scheduling } \\
\text { - } \quad \begin{array}{l}\text { BF8- Automated generation of } \\
\text { models and documents }\end{array}\end{array}$ & .854 & \\
\hline $\begin{array}{l}\text { LP3- Batch } \\
\text { size }\end{array}$ & $\begin{array}{l}\text { - } \quad \text { BF5-4D model-based scheduling } \\
\text { BF8- Automated generation of } \\
\text { models and documents } \\
\text { BF2- Maintenance of information } \\
\text { integrity }\end{array}$ & .859 & \\
\hline $\begin{array}{l}\text { LP5-Visual } \\
\text { management }\end{array}$ & $\begin{array}{l}\text { - } \quad \text { BF3- Controlling life cycle data } \\
\text { BF8- Automated generation of } \\
\text { models and documents } \\
\text { BF4- Support for augmented } \\
\text { reality }\end{array}$ & .810 & \\
\hline $\begin{array}{c}\text { LP8- } \\
\text { Standardize }\end{array}$ & 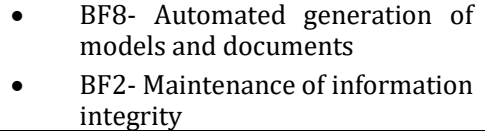 & .930 & $\begin{array}{r}\text { Table VI. Reliability test } \\
\text { analysis }\end{array}$ \\
\hline
\end{tabular}


The second analysis performed for the closed form questions was the correlation analysis, which was applied to the subscales 'reduce variability', 'reduce cycle-time', 'reduce batch-size', 'visual management', and 'standardize' to provide statistical evidence for the existence of a linear relationship between the same pairs of variables in the population. It was evident that a strong correlation between the sub-scales is present with most of the sub-scales scoring a high positive correlation, a minimum of $r$ $(\mathrm{df}=20)=.764, \mathrm{p}$-value $<.01$ between reduce variability and standardize and a maximum of $r(\mathrm{df}=20)$ $=.928, \mathrm{p}$-value $<.01$ between standardize and reduce cycle time. This strong correlation between the lean principles is also evident in the literature. Table IV shows the results of the correlation test.

\begin{tabular}{|c|c|c|c|c|c|c|c|}
\hline & & $\begin{array}{r}\text { Reduce } \\
\text { Variability }\end{array}$ & Cycle Time & size $^{\text {Batch }}$ & \begin{tabular}{l}
\multicolumn{1}{c}{ Visual } \\
manageme \\
nt
\end{tabular} & ze ${ }^{\text {Standardi }}$ & \\
\hline \multirow{3}{*}{$\begin{array}{c}\text { LP1- } \\
\text { Variability }\end{array}$} & Pearson & 1 & $.885^{* *}$ & $.836^{* *}$ & $.787^{* *}$ & $.764^{* *}$ & \\
\hline & $\begin{array}{l}\text { Sig. (2- } \\
\text { tailed) }\end{array}$ & & .000 & .000 & .000 & .000 & \\
\hline & $\mathrm{N}$ & 21 & 21 & 21 & 21 & 21 & \\
\hline \multirow[t]{3}{*}{$\begin{array}{c}\text { LP2- } \\
\text { Cycle Time }\end{array}$} & $\begin{array}{r}\text { Pearson } \\
\text { Correlation }\end{array}$ & $.885^{* *}$ & 1 & $.910^{* *}$ & $.886^{* *}$ & $.928^{* *}$ & \\
\hline & $\begin{array}{l}\text { Sig. (2- } \\
\text { tailed) }\end{array}$ & .000 & & .000 & .000 & .000 & \\
\hline & $\mathrm{N}$ & 21 & 21 & 21 & 21 & 21 & \\
\hline \multirow[t]{3}{*}{$\begin{array}{c}\text { LP3- } \\
\text { Batch size }\end{array}$} & $\begin{array}{r}\text { Pearson } \\
\text { Correlation }\end{array}$ & $.836^{* *}$ & $.910^{* *}$ & 1 & $.778^{* *}$ & $.907^{* *}$ & \\
\hline & $\begin{array}{l}\text { Sig. (2- } \\
\text { tailed) }\end{array}$ & .000 & .000 & & .000 & .000 & \\
\hline & $\mathrm{N}$ & 21 & 21 & 21 & 21 & 21 & \\
\hline \multirow{3}{*}{$\begin{array}{l}\quad \text { LP5- } \\
\text { Visual } \\
\text { managemen } \\
t\end{array}$} & $\begin{array}{r}\text { Pearson } \\
\text { Correlation }\end{array}$ & $.787^{* *}$ & $.886^{* *}$ & $.778^{* *}$ & 1 & $.775^{* *}$ & \\
\hline & $\begin{array}{l}\text { Sig. (2- } \\
\text { tailed) }\end{array}$ & .000 & .000 & .000 & & .000 & \\
\hline & $\mathrm{N}$ & 21 & 21 & 21 & 21 & 21 & \\
\hline \multirow[t]{3}{*}{$\begin{array}{c}\text { LP8- } \\
\text { Standardize }\end{array}$} & $\begin{array}{r}\text { Pearson } \\
\text { Correlation }\end{array}$ & $.764^{* *}$ & $.928^{* *}$ & $.907^{* *}$ & $.775^{* *}$ & 1 & \\
\hline & $\begin{array}{l}\text { Sig. (2- } \\
\text { tailed) }\end{array}$ & .000 & .000 & .000 & .000 & & Table VII. \\
\hline & $\mathrm{N}$ & 21 & 21 & 21 & 21 & 21 & Correlation Test Results \\
\hline
\end{tabular}

**. Correlation is significant at the 0.01 level (2-tailed).

Finally, based on the statistical analysis performed in this section, we were able to modify the theoretical interaction model found in Figure 1 from the previous section. The p-value of each component found in the new theoretical interaction model is found in Table 8, a positive p-value indicate the strength of the linear statistical relationship between the components. A p-value close to (1) with a significance of less than (0.05) indicate a strong statistical linear relationship. Figure 2 shows the final interaction model. The numbers found on each arrow in this figure present the $\mathrm{p}$-value from the Bivariate correlation test conducted for each element.

\begin{tabular}{|c|c|c|c|}
\hline Path & $\mathrm{p}$-value & $\mathrm{e}^{\text {Significanc }}$ & \\
\hline $\begin{array}{l}\text { BF2- Maintenance of information integrity } \rightarrow \text { LP1- } \\
\text { Reduce variability }\end{array}$ & .709 & $<0.05^{* *}$ & \\
\hline $\begin{array}{l}\text { BF2- Maintenance of information integrity } \rightarrow \text { LP2- } \\
\text { Reduce cycle-time }\end{array}$ & .846 & $<0.05^{* *}$ & \\
\hline $\begin{array}{l}\text { BF2- Maintenance of information integrity } \rightarrow \text { LP3- } \\
\text { Reduce batch-size }\end{array}$ & .851 & $<0.05^{* *}$ & \\
\hline $\begin{array}{l}\text { BF2- Maintenance of information integrity } \rightarrow \text { LP8- } \\
\text { Standardize }\end{array}$ & .928 & $<0.05^{* *}$ & \\
\hline $\begin{array}{l}\text { BF3- Controlling life-cycle data } \rightarrow \text { LP1- Reduce } \\
\text { variability }\end{array}$ & .726 & $<0.05^{* *}$ & \\
\hline $\begin{array}{l}\text { BF3- Controlling life-cycle data } \rightarrow \text { LP2- Reduce } \\
\text { cycle-time }\end{array}$ & .739 & $<0.05^{* *}$ & \\
\hline $\begin{array}{l}\text { BF3- Controlling life-cycle data } \rightarrow \text { LP5- Use visual } \\
\text { management }\end{array}$ & .740 & $<0.05^{* *}$ & Table VIII. Correlation Test \\
\hline $\begin{array}{l}\text { BF4- Support Augmented reality } \rightarrow \text { LP5- Use visual } \\
\text { management }\end{array}$ & .802 & $<0.05^{* *}$ & $\begin{array}{r}\text { Results for Each BIM } \\
\text { Component }\end{array}$ \\
\hline
\end{tabular}




\begin{tabular}{|c|c|c|}
\hline $\begin{array}{l}\text { BF5-4D model-based scheduling } \rightarrow \text { LP1- Reduce } \\
\text { variability }\end{array}$ & .567 & $0.07^{* *}$ \\
\hline $\begin{array}{l}\text { BF5-4D model-based scheduling } \rightarrow \text { LP2- Reduce } \\
\text { cycle-time }\end{array}$ & .610 & $<0.05^{* *}$ \\
\hline $\begin{array}{l}\text { BF5-4D model-based scheduling } \rightarrow \text { LP3- Reduce } \\
\text { batch-size }\end{array}$ & .647 & $<0.05^{* *}$ \\
\hline $\begin{array}{l}\text { BF5-4D model-based scheduling } \rightarrow \text { LP5- Use } \\
\text { visual management }\end{array}$ & .531 & $0.013^{*}$ \\
\hline $\begin{array}{l}\text { BF8- Automated generation of models and } \\
\text { documents } \rightarrow \text { LP2- Reduce cycle-time }\end{array}$ & .849 & $<0.05^{* *}$ \\
\hline $\begin{array}{l}\text { BF8- Automated generation of models and } \\
\text { documents } \rightarrow \text { LP3- Reduce batch-size }\end{array}$ & .800 & $<0.05^{* *}$ \\
\hline $\begin{array}{l}\text { BF8- Automated generation of models and } \\
\text { documents } \rightarrow \text { LP8- Standardize }\end{array}$ & .895 & $<0.05^{* *}$ \\
\hline BF7- Collaboration $\rightarrow$ LP1- Reduce variability & .618 & $<0.05^{* *}$ \\
\hline BF7- Collaboration $\rightarrow$ LP3- Reduce batch-size & .774 & $<0.05^{* *}$ \\
\hline
\end{tabular}

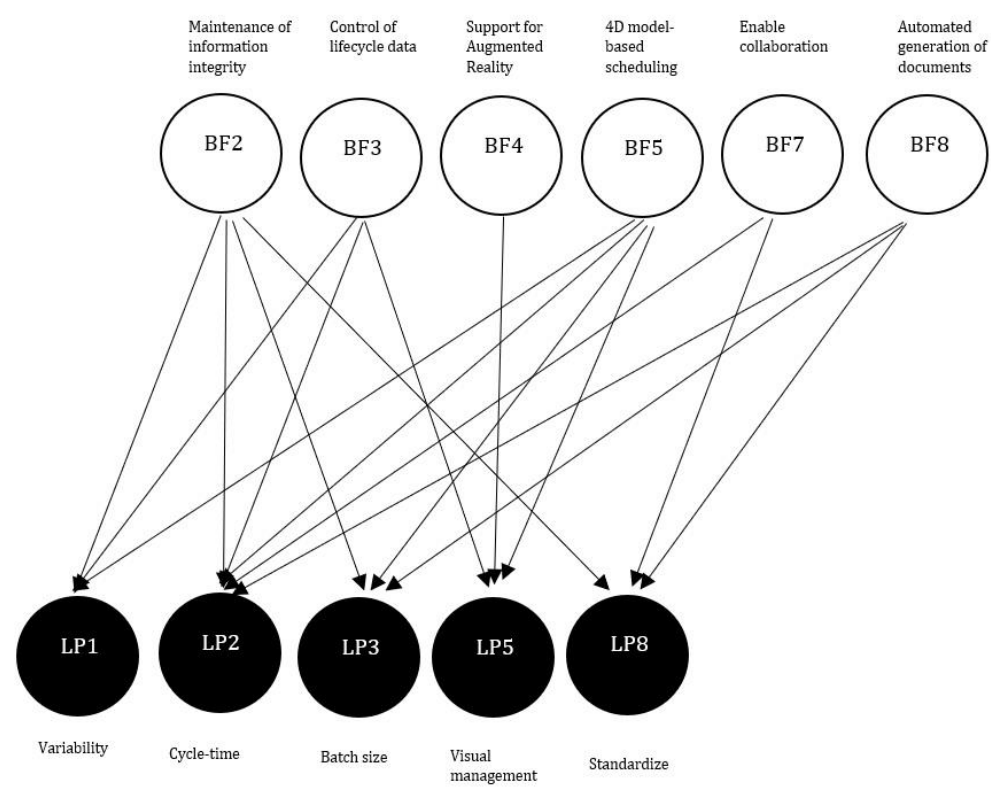

Figure 2. Final

For the open-ended questions found in the second section of this questionnaire, the results can be found in Table VI. In this table, each comment is analysed for frequent keywords that can be used as evidence of the synergy between BIM functionalities and lean principles. These keywords (themes) were then used in the synergy matrix found in the discussion section. The comment code numbers are added to Table VIII in the discussion section to facilitate finding the comment and themes in this table.

\begin{tabular}{|c|c|c|c|}
\hline $\begin{array}{l}\text { Comment } \\
\text { code } \\
\text { number }\end{array}$ & Comments & Theme & Rating \\
\hline $1-1$ & \multirow{2}{*}{$\begin{array}{l}\text { Accuracy on site saves time and maximises efficiency. } \\
\text { It's a qualified answer, because the surveyor would have to be } \\
\text { competent in BIM }\end{array}$} & Efficiency & 1 \\
\hline $1-2$ & & Competency & 0 \\
\hline $1-3$ & $\begin{array}{l}\text { Functionality of BIM can provide these and other insights, } \\
\text { often this valuable function is not invested in early enough }\end{array}$ & Competency & 1 \\
\hline $1-4$ & $\begin{array}{l}\text { BIM can improve reporting of inspections, if used } \\
\text { correctly, however insufficient knowledge of the technology } \\
\text { could lead to errors. }\end{array}$ & $\begin{array}{r}\text { Process } \\
\text { Facilitation }\end{array}$ & 1 \\
\hline $1-4$ & $\begin{array}{l}\text { BIM can improve reporting of inspections, if used correctly, } \\
\text { however insufficient knowledge of the technology could } \\
\text { lead to errors. }\end{array}$ & Knowledge & 0 \\
\hline $1-5$ & $\begin{array}{l}\text { BIM is a process we follow to achieve Building Data Store that } \\
\text { helps all users in coordination and integration from the } \\
\text { beginning. }\end{array}$ & $\begin{array}{r}\text { Process } \\
\text { Facilitation }\end{array}$ & 0 \\
\hline $2-1$ & Conflicts and clash detection are easier in BIM than CAD & Process & 1 \\
\hline
\end{tabular}


It is only as accurate as the information entered originally, therefore if that information was wrong, then any reporting will also be wrong.

The information stored is fully coordinated and computable

2-3 where it helps all team members in making effective meetings and regular computations.

This is only possible if the characters in the industry are

3-1 trained with a BIM-visualising mind-set. If you think in 2D drawings and your schedules are text as opposed to a generated list of elements, this will not be effective.

$\mathrm{BIM}$ is beneficial in this sense, however, there will always be

3-2 unexpected repair costs - BIM go a long way to minimise these chances.

It's an aspiration today. Too many practices are using BIM just for visual purposes

A 4D model cannot replace a physical inspection to assess the extent of damage and scale of repair needed.

$3-5$

The Process of BIM is meant for client satisfaction.

$4-1$

Surveyors will need to be BIM competent

$5-1$

This is a theoretical agreement with the question. A building surveyors skill set includes understanding the effects of building performance

We need to consider usage of the property rather than just the

5-2 building aspects - current thinking is that human intervention in property creates a significant variance to intended (design) performance - usually resulting in underperformance

The Process of BIM which is reflected by using different tools as Revit software is a purpose built for BIM and helps to store

5-3 all the information starting from the project information and property data that are used in energy simulations and other studies.

However, if time per report is reduced the number of

7-1 reports expected will increase not leading to any reduction in workload in terms of time at work

The BIM process helps in minimizing work hours where

7-2 users invest their time on different new projects by avoiding rework and chasing modifications as the conventional process do.

The BIM process helps in minimizing work hours where users invest their time on different new projects by avoiding rework and chasing modifications as the conventional process do.

The current state of AR requires the user to manually add inputs, which can result in increased human error

I've used a Hololens on a construction project before and it will

8-2 be absolutely fantastic in QC-ing sites.

Integrated AR in BIM can prove incredibly useful, but it must

8-3 be set up properly and with the correct information inputted only one element of incorrect information could result in the entire report being wrong.

This is a recent development. It requires competency and

8-4 vision of the practitioners.

Again, depends on the data available and the reliability of that

8-5 data - this is an information set which will take time to develop and adopt for buildings in-use

Again, depends on the data available and the reliability of that

8-5 data - this is an information set which will take time to develop and adopt for buildings in-use

Physical inspections are the best way to validate reports of

8-6 building condition, through the augmented reality material condition may not be able to be assessed.
Facilitation

Efficiency

Efficiency

Knowledge

Efficiency

Visual

Process

Facilitation

Process

Facilitation

Competency

Knowledge

Efficiency

0

Process

Facilitation

Process

Facilitation

Process

Facilitation

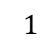

Efficiency

Efficiency

Process

Facilitation

Efficiency

0

Competency

Efficiency

0

Competency

$-1$

Competency

$-2$

Table IX. Coding Analysis for the Unstructured Data

The frequency for the themes measured in the open question section of the questionnaire is shown in Figure 3. The highest frequency measured was found to be 32 percent for both the 'efficiency' and 'process facilitation' category. The second highest frequency was for the category 'knowledge' with a frequency of 21 percent. The lowest frequency was found to be 3 percent for the visual category. The high frequencies emphasis the role of BIM on efficiency, and process facilitation. 
Regarding the rating results, for the category 'efficiency' the average rating was close to zero. This indicates that the perception of BIM improving the efficiency is seen as neutral by the participants. The average rating for the category 'competency' was close to negative one. This indicates that the participants' perception regarding employing the different BIM functionalities effectively requires a high level of competency by the users. For the 'knowledge' and 'process facilitation' categories, the average participant rating for each category was found to be close to one. This can indicate that knowledge and efficient use of BIM can be positively correlated, as the user's knowledge in the method is increased, the more efficient BIM becomes. Finally, the positive average rating for 'process facilitation' indicate that indeed BIM functionalities can improve the processes involved in the various activities in building surveying.

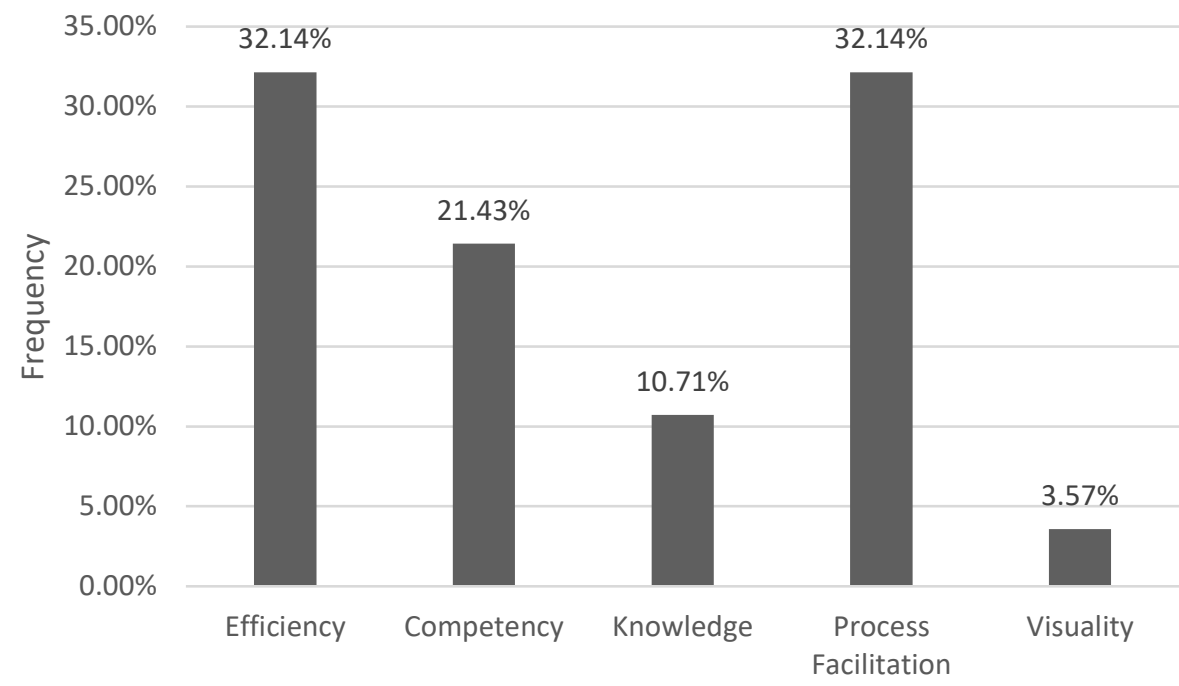

Category

\section{Interaction Matrix}

The interaction matrix found in Table $\mathrm{X}$ compiled the BIM functionalities against the lean principles that are relevant to the types of services provided by a building surveyor. The numbers found in each cell of the matrix refer to indexes which present evidence to support these interactions. These indexes can be found in Table XI. Both positive and negative interactions were found in this study. The negative interactions are found in a number bound by brackets in each cell of the interaction matrix. 


\begin{tabular}{|c|c|c|c|c|c|c|c|c|}
\hline $\begin{array}{l}\text { Lean principles } \\
\text { BIM functionalities }\end{array}$ & 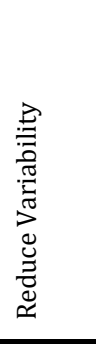 & 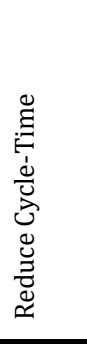 & 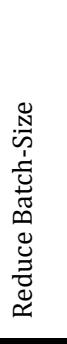 & 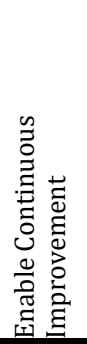 & 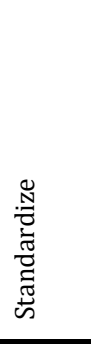 & 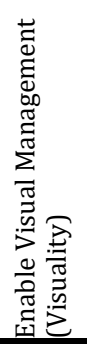 & 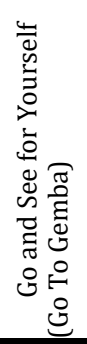 & 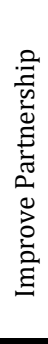 \\
\hline Visualization of Form & $\begin{array}{l}1,10 \\
(2)\end{array}$ & 1, (2), & & & & 15 & 24 & 28 \\
\hline $\begin{array}{l}\text { Maintenance of } \\
\text { Information Integrity }\end{array}$ & 6,13 & 4,13 & 4 & & 4 & 22 & & 12 \\
\hline $\begin{array}{l}\text { Controlling Life-Cycle } \\
\text { Cost Data }\end{array}$ & $16,(9)$ & 23,25 & & 25 & & 23 & & \\
\hline $\begin{array}{l}\text { Support Augmented } \\
\text { Reality }\end{array}$ & (19) & & (19) & & & 20 & & \\
\hline $\begin{array}{l}\text { Automated Generation } \\
\text { of } 4 \text { D Modelling, } \\
\text { Including Time } \\
\text { Scheduling }\end{array}$ & 11 & 11 & 11 & & & & & \\
\hline $\begin{array}{l}\text { Take Advantage of } \\
\text { Cloud Computing }\end{array}$ & $3,(21)$ & 3 & & & & 3 & & \\
\hline $\begin{array}{l}\text { Enable Collaboration } \\
\text { and Interoperability }\end{array}$ & 8 & & 8 & 27 & & & & 27 \\
\hline $\begin{array}{l}\text { Coordinate Sequences } \\
\text { of Steps }\end{array}$ & (7) & (7) & & & 14 & & & \\
\hline $\begin{array}{l}\text { Real Time Evaluation } \\
\text { of Property Data }\end{array}$ & $11,(9)$ & 11 & 11 & & 23 & & & \\
\hline $\begin{array}{l}\text { Automated Generation } \\
\text { of Models and } \\
\text { Documents }\end{array}$ & $\begin{array}{l}17,26, \\
(5)\end{array}$ & 17 & 18 & & 18,26 & & & \\
\hline
\end{tabular}
*The numbers found in the cells of the interaction matrix table refer to indexes that are explained in the table
below. The numbers inside the brackets present negative interactions.

Table X. Interaction Matrix

\begin{tabular}{|c|c|c|}
\hline $\begin{array}{l}\text { Index } \\
\text { Number }\end{array}$ & Explanation & Source \\
\hline 1 & $\begin{array}{l}\text { The visualization of form can assist the building } \\
\text { surveyor in getting the inspection quality right the first } \\
\text { time }\end{array}$ & $\begin{array}{l}\text { Quantitative results analysis } \\
\text { found in section } 4\end{array}$ \\
\hline (2) & $\begin{array}{l}\text { Incompetent knowledge and awareness of BIM } \\
\text { functionalities can lead to errors }\end{array}$ & $\begin{array}{l}\text { Qualitative results analysis found } \\
\text { in section } 4\end{array}$ \\
\hline 3 & $\begin{array}{l}\text { Point cloud surveying enables the surveyor to capture } \\
\text { a very complete set of measurements and other } \\
\text { relevant data regarding the space inside of a property } \\
\text { which is then transferred to a BIM software that would } \\
\text { render the scanned area intensely along with all the } \\
\text { information captured for each point. }\end{array}$ & (Klaschka, 2014; Xu et al., 2018) \\
\hline 4 & $\begin{array}{l}\text { The data stored in a BIM model can later allow the } \\
\text { surveyor to revisit this data and apply any as built } \\
\text { changes without the need to visit the site. This would } \\
\text { also allow the surveyor to obtain access to restricted } \\
\text { areas that are occupied by tenants. }\end{array}$ & $\begin{array}{l}\text { (Klaschka, 2014; Yang et al., } \\
\text { 2020) }\end{array}$ \\
\hline (5) & $\begin{array}{l}\text { Insufficient Knowledge of the technology can lead to } \\
\text { errors resulting from incompetency }\end{array}$ & $\begin{array}{l}\text { Qualitative results analysis found } \\
\text { in section } 6\end{array}$ \\
\hline 6 & $\begin{array}{l}\text { BIM allows for storing information once without } \\
\text { repetition increasing the quality of the information } \\
\text { presented in the surveyor's reports }\end{array}$ & $\begin{array}{l}\text { Quantitative results analysis } \\
\text { found in section } 6\end{array}$ \\
\hline (7) & $\begin{array}{l}\text { Error in reporting starts with the accuracy of } \\
\text { information entered by the surveyor. As some BIM } \\
\text { softwares require a significant amount of human input } \\
\text { to process information, the quality of reports would } \\
\text { depend on the quality of information entered by the } \\
\text { surveyor. }\end{array}$ & $\begin{array}{l}\text { Qualitative results analysis found } \\
\text { in section } 6\end{array}$ \\
\hline 8 & $\begin{array}{l}\text { BIM allows for effective collaboration as the } \\
\text { information stored in a BIM model can be accessed } \\
\text { unrestrictedly by the different stakeholders. Reducing } \\
\text { any clashes that may result from manual take-offs }\end{array}$ & $\begin{array}{l}\text { (Barnes, 2019; Zhang, Chen, et al., } \\
\text { 2015) }\end{array}$ \\
\hline (9) & The current BIM capabilities lack accuracy in terms of & Qualitative results analysis found \\
\hline
\end{tabular}


estimation of damage scale and repair costs

BIM user can take advantage of visual and aesthetic management functionalities to reduce variability

4D modelling, which includes time scheduling,

provides the surveyor with the right tools to forecast

to a certain degree the time and costs associated with repairs and maintenance

BIM improves the aesthetic and functional decision-

making process, which in turn improves the reliability of services provided by the surveyor.

Enabling access to online database and historic data allow the surveyor in measuring accurately the current state of a property which in turn allows for more accurate reporting

As BIM enables automated estimation of schedules and costs, this would lead to a more systematic approach to sequencing the processes involved in building surveying activities

Not only does BIM models allow the surveyor to visit the worksite virtually, but also each object in this model stores geometric and intelligent information that can be accessed instantly.

BIM functionalities allow for increased accuracy interms of measuring the space performance

The automated generation of models and documents

allow the surveyor to produce more efficiently in less the time required, thus reducing cycle time for the activities involved in inspecting and reporting The automated generation of models and documents

18 allow the surveyor to complete more tasks with in less the time required, leading to a reduction in batch sizes The current state of augmented reality is hampered by the degree of human input required, which can lead to increased human error. Thus, this technology requires competency and vision of the practitioners.

Enabling augmented reality in a BIM model allows the surveyor to verify and validate inspections and reporting

Point cloud modelling offers an effective alternative to physical site inspections; however, the current state of the technology requires a more standardized

(21) geometric quality assessment to enable reliability and reusability for future users on a micro-scale level of measurement

BIM creates a comprehensive database where information regarding location, functionality and specification of a space can be stored and retrieved. This database is frequently update and revised to incorporate new information throughout the property's lifecycle which would allow the surveyor to effectively plan and report on any future renovations and building upgrades

As BIM models store information regarding the current state of a property, this information can be used later to assess the building performance ie energy performance or space utilization for that property

The 3D visualization that BIM models provide, allow the surveyor to check for and compare building specifications and requirements against the actual performance

BIM models reduce the inputs required for $2 \mathrm{D} C \mathrm{CAD}$ models to evaluate the energy efficiency of a property.

This can be done at an early stage of the property's evaluation which would allow more time to apply improvements or modifications

As the flow of information is reduced in a project, compared to a 2D CAD information flow, reporting is produced more accurately due to effective management, tracking, and distribution of the available information

Integration of other stakeholders within a project

allows for increased trust and confidence between the different parties that would extend beyond individual projects in section 6

Qualitative results analysis found

in section 6

Quantitative results analysis

found in section 6

Qualitative results analysis found in section 6

Quantitative results analysis

found in section 6

(Klein et al., 2012)

(Hardin and Mccool, 2015

Khaddaj and Srour, 2016)

Qualitative results analysis found in section 6

Quantitative results analysis found in section 6

Quantitative results analysis found in section 6

Qualitative results analysis found in section 6

Quantitative results analysis found in section 6

(Bonduel et al., 2017)

(Khaddaj and Srour, 2016; Klein et al., 2012; Oskouie et al., 2012)

Quantitative results analysis found in section 6 ;

Oskouie et al. ,2012

(Eastman et al., 2018; Li and Froese, 2016)

(Eastman et al., 2018)

(Daniotti, 2019; Hardin and Mccool, 2015)

(de Carvalho et al., 2017; Sacks et al., 2010; Wilkinson, 2005)

(Gozali et al., 2019; Zhang et al., 2018)
Table XI. Evidence for BIM Functionalities 


\section{Discussion}

The paper presented an argument on how BIM can contribute to improving the services associated with the Building surveying practice. The study also presented an insight on how this sector views the introduction of new technologies into the working environment. The contrasting views from the literature and the questionnaire results indicate that the building surveying sector is lagging behind other sectors. The interaction matrix can be used as a guideline for firms and building surveyors who wish to implement BIM. From the data collected, the study was able to identify the lean principles that had the highest concentration of interactions in building surveying practices. Looking through the interaction matrix, the principles with the highest interactions observed were 'Reduce Variability' and 'Reduce Cycle-Time'. This, along with 'Reduce Batch-Size' and 'Standardize' indicates that BIM functionalities can eliminate waste through the promotion of these principles.

Furthermore, as waste is reduced, the services provided by the building surveyor for the clients are improved, leading to an increase in value from a client's point of view and with the reduction in batchsize, quality services is provided to clients in less the time required. Interactions between various BIM functionalities with lean principles such as 'Enable Continuous Improvement', 'Standardize', and 'Enable Visual Management', can lead to enhancing the value stream in the sequence of processes involved that lead to producing value for customers. BIM functionality, collaboration, facilitates trust and confidence between the different stakeholders and with the introduction of advanced communication techniques, sharing and accessing information is facilitated which can lead to improved partnership. Enhanced partnership in the building surveying practice can lead to enhancing the quality of information exchanged through the services provided.

Accuracy in the services provided by a building surveyor can be increased through the introduction of advanced visualization techniques such as VR and AR. In the interaction matrix, these this functionality interacts positively with the visual management principle. The interaction with variability and batch-size, however, is a negative interaction. This can indicate that the technology is yet to be fully utilized in the surveying practice or it may indicate that education and training is required to enable the full potential of this functionality. While the interactions between the two concepts were found to be mostly positive, a few interactions were negative. This is due to several issues such as the quality of training provided, lack of knowledge and awareness, as well as increased human input. Although the increased human input can be classified as necessity type of waste due to current technology, poor training quality and lack of knowledge and awareness can be classified as type 2 Muda that leads to a reduction in accuracy of the information presented in BIM models which needs to be eliminated to further improve the interactions between the two concepts.

\section{Conclusion and Future Works}

Different BIM functionalities and lean production principles that were conceptualized in previous literature were examined to find evidence of interconnections between the two concepts. Furthermore, as BIM has been recently introduced and adopted by a significant number of building surveyor organizations, a questionnaire was conducted to fill the gap and provide further evidence for the interaction between the two concepts. BIM functionalities were selected based on two priorities: relevance to building surveying and potential to improve value and flow.

The interaction matrix between BIM functionalities and lean principles show that the BIM functionalities that had the most interactions in building surveying were the visualization of form, maintenance of information integrity, and the automated generation of models and documents. Negative interactions were also observed. This is due to lack or incompetent knowledge and awareness which can lead to increased human error and rework, which can lead to increased variability and cycle time. This can be avoided by improving the knowledge base for individuals regarding the different BIM concepts and functionalities.

Regarding the enabling of augmented reality within BIM software, due to the increased human inputs, which again can lead to an increase in human error. The current state of this technology may be hampered, however, once new technologies such as cognitive machine learning is introduced this can reduce the amount of input required.

These evidences show that BIM can lead to a reduction of waste in terms of variability, cycle time, and batch size. Moreover, reducing these types of wastes can lead to standardization and continuous improvement as the technology and the BIM knowledge for the surveyor is improved. Thus, BIM functionalities can lead to improving the value and flow for processes involved in building surveying practices through the reduction of waste. Finally, the evidence provided in this study shows the potential of collaboration in projects in terms of increasing value and reducing waste for the building surveying practices. 
In practical terms, the findings in the interaction matrix can be used as a guideline by individual and organizations in the building surveying practice who wish to implement BIM. The outcome of this research can be further developed in the future to incorporate IoT technologies and big data. Furthermore, case studies can be employed in future research to identify new interactions.

\section{References}

Abdallah, A.B., Dahiyat, S.E. and Matsui, Y. (2019), "Lean management and innovation performance: Evidence from international manufacturing companies", Management Research Review, Vol. 42 No. 2, pp. 239-262.

Aibinu, A. and Venkatesh, S. (2014), "Status of BIM adoption and the BIM experience of cost consultants in Australia", Journal of Professional Issues in Engineering Education and Practice, Vol. 140 No. 3, pp. 1-10.

Akinade, O.O., Oyedele, L.O., Ajayi, S.O., Bilal, M., Alaka, H.A., Owolabi, H.A. and Arawomo, O.O. (2018), "Designing out construction waste using BIM technology: Stakeholders' expectations for industry deployment", Journal of Cleaner Production, Vol. 180, pp. 375-385.

Akponeware, A.O. and Adamu, Z.A. (2017), "Clash detection or clash avoidance? An investigation into coordination problems in 3D BIM", Buildings, Vol. 7 No. 3, pp. 1-28.

Alan, H., Barry, M., Roger, W., Mohmad, K. and Shiyao, K. (2017), "Ireland's BIM Macro Adoption Study: Establishing Ireland's BIM Maturity", CITA BIM Gathering 2017, pp. 32-40.

Alhuraish, I., Robledo, C. and Kobi, A. (2016), "Assessment of Lean Manufacturing and Six Sigma operation with Decision Making Based on the Analytic Hierarchy Process", IFAC PapersOnLine, Elsevier B.V., Vol. 49 No. 12, pp. 59-64.

Ali, A.S. and Woon, C.J. (2013), "Issues and challenges faced by building surveyors in Malaysia", Structural Survey, Vol. 31 No. 1, pp. 35-42.

Andelin, M., Karhu, J. and Junnila, S. (2015), "Creating Shared Value in a Construction Project - A Case Study”, Procedia Economics and Finance, Elsevier B.V., Vol. 21 No. 15, pp. 446-453.

ANDÚJAR-MONTOYA, M.D., GALIANO-GARRIGÓS, A., RIZO-MAESTRE, C. and ECHARRIIRIBARREN, V. (2019), "Bim and Lean Construction Interactions: a State-of-the-Art Review", Building Information Modelling (BIM) in Design, Construction and Operations III, Vol. 1, pp. $1-13$.

Aziz, R.F. and Hafez, S.M. (2013), "Applying lean thinking in construction and performance improvement", Alexandria Engineering Journal, Faculty of Engineering, Alexandria University, Vol. 52 No. 4, pp. 679-695.

Bamana, F., Lehoux, N. and Cloutier, C. (2019), "Simulation of a Construction Project: Assessing Impact of Just-in-Time and Lean Principles", Journal of Construction Engineering and Management, Vol. 145 No. 5, pp. 1-15.

Banawi, A. and Bilec, M.M. (2014), "A framework to improve construction processes: Integrating lean, green and six sigma", International Journal of Construction Management, Taylor \& Francis, Vol. 14 No. 1, pp. 45-55.

Barnes, P. (2019), BIM in Principle and in Practice, BIM in Principle and in Practice, Third Edit., Thomas Telford Limited, available at:https://doi.org/10.1680/bimpp.63693.

Bashir, A.M., Suresh, S., Oloke, D.A., Proverbs, D.G. and Gameson, R. (2013), "The Application of Lean Construction Tools in United Kingdom Construction Organisations: Findings From a Qualitative Inquiry", AEI 2013, pp. 64-73. 
Belhadi, A., Kamble, S.S., Zkik, K., Cherrafi, A. and Touriki, F.E. (2020), “The integrated effect of Big Data Analytics, Lean Six Sigma and Green Manufacturing on the environmental performance of manufacturing companies: The case of North Africa”, Journal of Cleaner Production, Vol. 252, available at:https://doi.org/10.1016/j.jclepro.2019.119903.

Bicheno, J. (2016), The Lean Toolbox for Service Systems, Picsie Books, Buckingham, available at: http://orca.cf.ac.uk/id/eprint/25631.

Bicheno, J. and Holweg, M. (2016), "THE LEAN TOOLBOX A HANDBOOK FOR LEAN TRANSFORMATION 5th Edition", No. December.

Bonduel, M., Bassier, M., Vergauwen, M., Pauwels, P. and Klein, R. (2017), "Scan-to-bim output validation: Towards a standardized geometric quality assessment of building information models based on point clouds", International Archives of the Photogrammetry, Remote Sensing and Spatial Information Sciences - ISPRS Archives, Vol. 42 No. 2W8, pp. 45-52.

Brumana, R., Oreni, D., Barazzetti, L., Cuca, B., Previtali, M. and Banfi, F. (2020), "Survey and Scan to BIM Model for the Knowledge of Built Heritage and the Management of Conservation Activities", Digital Transformation of the Design, Construction, and Management Processes of the Built Environment, Vol. 391-400.

de Carvalho, A.C.V., Granja, A.D. and da Silva, V.G. (2017), "A systematic literature review on integrative lean and sustainability synergies over a building's lifecycle", Sustainability (Switzerland), Vol. 9 No. 7, available at:https://doi.org/10.3390/su9071156.

Czifra, G., Szabó, P., Míkva, M. and Vaňová, J. (2019), "Lean principles application in the automotive industry", Acta Polytechnica Hungarica, Vol. 16 No. 5, pp. 43-62.

Daniotti, B. (2019), Digital Transformation of the Design, Construction and Management Processes of the Built Environment.

Deng, H., Hong, H., Luo, D., Deng, Y. and Su, C. (2020), "Automatic Indoor Construction Process Monitoring for Tiles Based on BIM and Computer Vision", Journal of Construction Engineering and Management, Vol. 146 No. 1, pp. 1-12.

Dombrowski, U. and Mielke, T. (2013), "Lean Leadership - Fundamental principles and their application”, Procedia CIRP, Elsevier B.V., Vol. 7, pp. 569-574.

Eastman, C., Teicholz, P., Sacks, R. and Lee, G. (2018), BIM Handbook: A Guide to Building Information Modeling for Owners, Designers, Engineers, Contractors, and Facility Managers, John Wiley \& Sons, Incorporated, Newark, UNITED STATES, available at: http://ebookcentral.proquest.com/lib/portsmouth-ebooks/detail.action?docID=5447327.

Elmaraghy, A., Voordijk, H. and Marzouk, M. (2018), "An exploration of BIM and lean interaction in optimizing demolition projects", IGLC 2018 - Proceedings of the 26th Annual Conference of the International Group for Lean Construction: Evolving Lean Construction Towards Mature Production Management Across Cultures and Frontiers, Vol. 1, pp. 112-122.

Esquenazi, A. and Sacks, R. (2006), "Evaluation of lean improvements in residential construction using computer simulation", Understanding and Managing the Construction Process: Theory and Practice - 14th Annual Conference of the International Group for Lean Construction, IGLC-14, pp. 137-149.

Forgues, D., Iordanova, I., Valdivesio, F. and Staub-French, S. (n.d.). "Rethinking the Cost Estimating Process through 5D BIM: A Case Study", Construction Research Congress 2012, pp. 778-786.

Ghaffarianhoseini, A., Tookey, J., Ghaffarianhoseini, A., Naismith, N., Azhar, S., Efimova, O. and Raahemifar, K. (2017), "Building Information Modelling (BIM) uptake: Clear benefits, understanding its implementation, risks and challenges", Renewable and Sustainable Energy Reviews, Vol. 75 No. December 2016, pp. 1046-1053. 
Goienetxea Uriarte, A., Ng, A.H.C. and Urenda Moris, M. (2020), "Bringing together Lean and simulation: a comprehensive review", International Journal of Production Research, Taylor \& Francis, Vol. 58 No. 1, pp. 87-117.

Gozali, S., Zekavat, P., Moon, S., Tang, L. and Moustafa, S. (2019), BIM Applications to Leveraging Lean Principles in Modern Construction.

Guo, J., Yuan, L. and Wang, Q. (2020), "Time and cost analysis of geometric quality assessment of structural columns based on 3D terrestrial laser scanning", Automation in Construction, Elsevier, Vol. 110 No. June 2019, p. 103014.

Han, K.K. and Golparvar-Fard, M. (2015), "Appearance-based material classification for monitoring of operation-level construction progress using 4D BIM and site photologs", Automation in Construction, Elsevier B.V., Vol. 53, pp. 44-57.

Hardin, B. and Mccool, D. (2015), BIM and Construction Management Proven Tools, Methods, and Workflow, Second Edi., John Wiley \& Sons, Incorporated.

Al Hattab, M. and Hamzeh, F. (2018), "Simulating the dynamics of social agents and information flows in BIM-based design", Automation in Construction, Elsevier, Vol. 92 No. September 2017, pp. 1-22.

Herrera, R.F., Sanz, M.A., Montalbán-Domingo, L., García-Segura, T. and Pellicer, E. (2019), "Impact of game-based learning on understanding lean construction principles", Sustainability (Switzerland), Vol. 11 No. 19, available at:https://doi.org/10.3390/su11195294.

Hochscheid, E. and Halin, G. (2019), "Micro BIM Adoption in Design Firms: Guidelines for Doing a BIM Implementation Plan", pp. 864-871.

Ilter, D. and Ergen, E. (2015), "BIM for building refurbishment and maintenance: current status and research directions", Structural Survey, Vol. 33 No. 3, pp. 228-256.

Issa, U.H. (2013), "Implementation of lean construction techniques for minimizing the risks effect on project construction time", Alexandria Engineering Journal, Faculty of Engineering, Alexandria University, Vol. 52 No. 4, pp. 697-704.

Iyer, K.N.S., Srivastava, P. and Srinivasan, M. (2019), "Performance implications of lean in supply chains: Exploring the role of learning orientation and relational resources", International Journal of Production Economics, Elsevier B.V., Vol. 216 No. June 2018, pp. 94-104.

Jeong, W.S., Chang, S., Son, J.W. and Yi, J.S. (2016), "BIM-integrated construction operation simulation for just-in-time production management", Sustainability (Switzerland), Vol. 8 No. 11, pp. 1-25.

Jing, S., Li, R., Niu, Z. and Yan, J. (2020), "The application of dynamic game theory to participant's interaction mechanisms in lean management", Computers and Industrial Engineering, Elsevier, Vol. 139 No. November 2019, p. 106196.

Johansson, M., Roupé, M. and Bosch-Sijtsema, P. (2015), "Real-time visualization of building information models (BIM)", Automation in Construction, Elsevier B.V., Vol. 54, pp. 69-82.

Jusselme, T., Rey, E. and Andersen, M. (2020), "Surveying the environmental life-cycle performance assessments: Practice and context at early building design stages", Sustainable Cities and Society, Elsevier, Vol. 52 No. October 2019, p. 101879.

Khaddaj, M. and Srour, I. (2016), "Using BIM to Retrofit Existing Buildings", Procedia Engineering, Elsevier B.V., Vol. 145, pp. 1526-1533.

\section{Klaschka, R. (2014), BIM in Small Practices: Illustrated Case Studies, RIBA Publishing.}

Klein, L., Li, N. and Becerik-Gerber, B. (2012), "Imaged-based verification of as-built documentation of operational buildings", Automation in Construction, Elsevier B.V., Vol. 21 No. 1, pp. 161- 
Kong, S.W.R., Lau, L.T., Wong, S.Y. and Phan, D.T. (2020), "A study on effectiveness of Building Information Modelling (BIM) on the Malaysian construction industry", IOP Conference Series: Materials Science and Engineering, Vol. 713 No. 1, available at:https://doi.org/10.1088/1757899X/713/1/012035.

Koseoglu, O. and Nurtan-Gunes, E.T. (2018), "Mobile BIM implementation and lean interaction on construction site: A case study of a complex airport project", Engineering, Construction and Architectural Management, Vol. 25 No. 10, pp. 1298-1321.

Lai, N.Y.G., Hoong Wong, K., Halim, D., Lu, J. and Siang Kang, H. (2019), "Industry 4.0 Enhanced Lean Manufacturing", Proceedings of 2019 8th International Conference on Industrial Technology and Management, ICITM 2019, IEEE, pp. 206-211.

Layek, S., Singh, R.K., Villuri, V.G.K., Koner, R., Soni, A. and Khare, R. (2020), “3D Reconstruction: An Emerging Prospect for Surveying", Applications of Geomatics in Civil Engineering, Vol. 33.

Lee, C.Y., Chong, H.Y. and Wang, X. (2018), "Enhancing BIM Performance in EPC Projects through Integrative Trust-Based Functional Contracting Model", Journal of Construction Engineering and Management, Vol. 144 No. 7, pp. 1-6.

Lee, P.C., Long, D., Ye, B. and Lo, T.P. (2020), "Dynamic BIM component recommendation method based on probabilistic matrix factorization and grey model", Advanced Engineering Informatics, Vol. 43 No. August 2019, available at:https://doi.org/10.1016/j.aei.2019.101024.

Lee, Y.C., Eastman, C.M. and Solihin, W. (2018), "Logic for ensuring the data exchange integrity of building information models", Automation in Construction, Elsevier, Vol. 85 No. June 2017, pp. $249-262$.

Lehr, J., Vitoux, R.R., Zavotsky, K.E., Pontieri-Lewis, V. and Colineri, L. (2019), "Achieving outcomes with innovative smart pump technology: Partnership, planning, and quality improvement”, Journal of Nursing Care Quality, Vol. 34 No. 1, pp. 9-15.

Li, P. and Froese, T.M. (2016), "Life-Cycle Assessment of High Performance, Low Cost Homes", Procedia Engineering, Elsevier B.V., Vol. 145, pp. 1322-1329.

Liao, L., Teo, E.A.L., Chang, R. and Li, L. (2020), "Investigating Critical Non-Value Adding Activities and Their Resulting Wastes in BIM-Based Project Delivery", Sustainability, Vol. 12 No. 1 , p. 355.

Liker, J.K. and Morgan, J.M. (2006), "The Toyota Way in Services: The Case of Lean Product Development", Academy of Management Perspectives, Vol. 20 No. 2, pp. 5-20.

Lodgaard, E., Ingvaldsen, J.A., Gamme, I. and Aschehoug, S. (2016), "Barriers to Lean Implementation: Perceptions of Top Managers, Middle Managers and Workers", Procedia CIRP, The Author(s), Vol. 57, pp. 595-600.

Mahdjoubi, L., Moobela, C. and Laing, R. (2013), "Providing real-estate services through the integration of 3D laser scanning and building information modelling", Computers in Industry, Elsevier B.V., Vol. 64 No. 9, pp. 1272-1281.

Maid, G.D. and Desai, G. (2019), "Enhancement of Productivity and Minimization of Waste using Lean Construction Techniques", pp. 6853-6858.

Mano, A.P., Gouvea da Costa, S.E. and Pinheiro de Lima, E. (2019), "Analysis of the production function in civil construction: a driver for lean construction", Journal of Lean Systems, Vol. 4, pp. 107-133.

Matthews, J., Love, P.E.D., Heinemann, S., Chandler, R., Rumsey, C. and Olatunj, O. (2015), "Real time progress management: Re-engineering processes for cloud-based BIM in construction", Automation in Construction, Elsevier B.V., Vol. 58, pp. 38-47. 
de Mattos Nascimento, D.L., Sotelino, E.D., Lara, T.P.S., Caiado, R.G.G. and Ivson, P. (2017), "Constructability in industrial plants construction: a BIM-Lean approach using the Digital Obeya Room framework", Journal of Civil Engineering and Management, Taylor \& Francis, Vol. 23 No. 8, pp. 1100-1108.

Meža, S., Turk, Ž. and Dolenc, M. (2014), "Component based engineering of a mobile BIM-based augmented reality system", Automation in Construction, Vol. 42, pp. 1-12.

Mill, T., Alt, A. and Liias, R. (2013), "Combined 3D building surveying techniques - terrestrial laser scanning (TLS) and total station surveying for BIM data management purposes", Journal of Civil Engineering and Management, Taylor \& Francis, Vol. 19 No. sup1, pp. S23-S32.

Nath, T., Attarzadeh, M., Tiong, R.L.K., Chidambaram, C. and Yu, Z. (2015), "Productivity improvement of precast shop drawings generation through BIM-based process re-engineering", Automation in Construction, Elsevier B.V., Vol. 54, pp. 54-68.

Nicholson, A. and Pakgohar, A. (2020), "Lean Thinking in a UK University Law Clinic: A Reflective Case Study", International Journal of Clinical Legal Education, Vol. 27, pp. 171-203.

Office, C. (2011), “Government Construction Strategy”, Construction, No. May.

Oliver, S., Seyedzadeh, S., Dawood, N. and Rodriguez, S. (2020), "Cost-Effective as-Built BIM Modelling Using 3D Point-Clouds and Photogrammetry Mini Review Current Trends in Civil \& Structural Engineering”, pp. 8-12.

Oraee, M., Hosseini, M.R., Papadonikolaki, E., Palliyaguru, R. and Arashpour, M. (2017), "Collaboration in BIM-based construction networks: A bibliometric-qualitative literature review", International Journal of Project Management, Elsevier Ltd, APM and IPMA, Vol. 35 No. 7, pp. 1288-1301.

Oskouie, P., Gerber, D.J., Alves, T. and Becerik-Gerber, B. (2012), "Extending the interaction of building information modeling and lean construction", IGLC 2012 - 20th Conference of the International Group for Lean Construction, Vol. 1 No. 617.

Paavola, S., Hannele, K., Tarja, M., Jenni, K. and Reijo, M. (2012), "BIM technologies and collaboration in a life-cycle project”, London, pp. 855-862.

Pamfilie, R., (Draghici), A.J.P. and Draghici, M. (2012), "The Importance of Leadership in Driving a Strategic Lean Six Sigma Management”, Procedia - Social and Behavioral Sciences, Vol. 58, pp. 187-196.

Park, J.H. and Lee, G. (2017), "Design coordination strategies in a 2D and BIM mixed-project environment: social dynamics and productivity", Building Research and Information, Taylor \& Francis, Vol. 45 No. 6, pp. 631-648.

Patacas, J., Dawood, N., Vukovic, V. and Kassem, M. (2015), "BIM for facilities management: Evaluating BIM standards in asset register creation and service life planning", Journal of Information Technology in Construction, Vol. 20 No. August, pp. 313-331.

Pearce, A. and Pons, D. (2013), "Implementing Lean Practices: Managing the Transformation Risks", Journal of Industrial Engineering, Vol. 2013, pp. 1-19.

Pitti, Y., Boton, C. and Forgues, D. (2019), "Combining BIM and Last Planner on Construction Sites: an Investigation of the Related Challenges", pp. 824-829.

Rajendran, P. and Pathrose, C.P. (2012), "Implementing BIM for waste minimisation in the construction industry", Proceedings of the 2nd International Conference on Management, No. June, pp. 557-570.

Rocha, G., Mateus, L., Fernandez, J. and Ferreira, V. (2020), “A Scan-to-BIM Methodology Applied to Heritage Buildings", pp. 47-65. 
Royal Institution of Chartered Surveyors (RICS). (2012), Building Survey, RICS Publishing, London.

Royal Institution of Chartered Surveyors (RICS). (2016), BIM for Building Surveyors, RICS Publishing, London.

Rudnick, M., Riezebos, J., Powell, D.J. and Hauptvogel, A. (2020), "Effective after-sales services through the lean servitization canvas", International Journal of Lean Six Sigma, Vol. ahead-ofp No. ahead-of-print, available at:https://doi.org/10.1108/ijlss-07-2017-0082.

Sacks, R. and Goldin, M. (2007), "Lean management model for construction of high-rise apartment buildings", Journal of Construction Engineering and Management, Vol. 133 No. 5, pp. 374384.

Sacks, R., Koskela, L., Dave, B.A. and Owen, R. (2010), "Interaction of lean and building information modeling in construction", Journal of Construction Engineering and Management, Vol. 136 No. 9, pp. 968-980.

Sapsford, R. and Jupp, V. (2006), Data Collection and Analysis, SAGE Publishing, London.

Sarhan, S. and Fox, A. (2013), "Barriers to implementing lean construction in the UK construction industry", The Built \& Human Environment Review, Vol. 6, pp. 1-17.

Sarhan, S., Pasquire, C., King, A. and Manu, E. (2018), "Institutional Waste within the UK Construction Procurement Context: A Conceptual Framework", Engineering Project Organization Journal, Vol. 8 No. 1, available at:https://doi.org/10.25219/epoj.2018.00102.

Silva, J.H.O., Mendes, G.H.S. and Cauchick-Miguel, P.A. Amorim, M. (2020), "Customer Experience Literature Analysis Based on Bibliometry", Exploring Service Science, available at:https://doi.org/https://doi.org/10.1007/978-3-030-38724-2_1.

Son, H., Kim, C. and Turkan, Y. (2015), "Scan-to-BIM-an overview of the current state of the art and a look ahead", 32nd International Symposium on Automation and Robotics in Construction and Mining: Connected to the Future, Proceedings, available at:https://doi.org/10.22260/isarc2015/0050.

Succar, B. and Kassem, M. (2015), "Macro-BIM adoption: Conceptual structures", Automation in Construction, Elsevier B.V., Vol. 57, pp. 64-79.

Succar, B., Sher, W. and Williams, A. (2012), "Measuring BIM performance: Five metrics", Architectural Engineering and Design Management, Vol. 8 No. 2, pp. 120-142.

Tauriainen, M., Marttinen, P., Dave, B. and Koskela, L. (2016), "The effects of BIM and lean construction on design management practices", Procedia Engineering, The Author(s), Vol. 164 No. June, pp. 567-574.

Tavakol, M. and Dennick, R. (2011), "Making Sense of Cronbach's Alpha", International Journal of Medical Education, Vol. 2, pp. 53-55.

Teicholz, P. (2013), BIM for Facility Managers, John Wiley \& Sons, Incorporated, New Jersey.

Thomas, H.R., Horman, M.J., De Souza, U.E.L. and Zavřski, I. (2002), "Reducing variability to improve performance as a lean construction principle", Journal of Construction Engineering and Management, Vol. 128 No. 2, pp. 144-154.

Tzedaki, V. and Kamara, J.M. (2013), "Capturing As-Built Information for a BIM Environment Using 3D Laser Scanner: A Process Model”, AEI 2013, pp. 486-495.

Vilar, F. and Santos, L.C. (2020), "An adaptive method for assessing the implementation degree of lean production", Vol. 5, pp. 104-125.

Volk, R., Stengel, J. and Schultmann, F. (2014), "Building Information Modeling (BIM) for existing buildings - Literature review and future needs", Automation in Construction, Elsevier B.V., 
Vol. 38, pp. 109-127.

Wilkinson, P. (2005), Construction Collaboration Technologies: The Extranet Evolution, Taylor \& Francis, New York.

Wilson, L. (2010), How to Implement Lean Manufacturing, The McGraw-Hill Companies.

Womack, J. and Jones, D. (2003), Lean Thinking: Banish Waste and Create Wealth in Your Corporation, Journal of the Operational Research Society, Vol. 48, available at:https://doi.org/10.1038/sj.jors.2600967.

Won, J., Cheng, J.C.P. and Lee, G. (2016), "Quantification of construction waste prevented by BIMbased design validation: Case studies in South Korea", Waste Management, Elsevier Ltd, Vol. 49, pp. $170-180$.

Wu, C., Xu, B., Mao, C. and Li, X. (2017), "Overview of bim maturity measurement tools", Journal of Information Technology in Construction, Vol. 22 No. January, pp. 34-62.

Xu, G., Li, M., Chen, C.H. and Wei, Y. (2018), “Cloud asset-enabled integrated IoT platform for lean prefabricated construction”, Automation in Construction, Elsevier, Vol. 93 No. May, pp. 123134.

Yang, L., Cheng, J.C.P. and Wang, Q. (2020), "Semi-automated generation of parametric BIM for steel structures based on terrestrial laser scanning data", Automation in Construction, Elsevier, Vol. 112 No. March 2019, p. 103037.

Yarmohammadi, S. and Ashuri, B. (2015), "Exploring the approaches in the implementation of BIMbased MEP coordination in the USA", Journal of Information Technology in Construction, Vol. 20 No. July, pp. 347-363.

Yin, X., Liu, H., Chen, Y., Wang, Y. and Al-Hussein, M. (2020), "A BIM-based framework for operation and maintenance of utility tunnels", Tunnelling and Underground Space Technology, Elsevier, Vol. 97 No. December 2019, p. 103252.

Zhang, B., Niu, Z. and Liu, C. (2020), "Lean Tools , Knowledge Management , and Lean Sustainability: The Moderating Effects of Study Conventions", available at:https://doi.org/10.3390/su12030956.

Zhang, C., Chen, J., Sun, X. and Hammad, A. (2015), "Lifecycle evaluation of building sustainability using BIM and RTLS", Proceedings - Winter Simulation Conference, IEEE, Vol. 2015-Janua, pp. 3236-3247.

Zhang, J., Seet, B.C. and Lie, T.T. (2015), "Building information modelling for smart built environments", Buildings, Vol. 5 No. 1, pp. 100-115.

Zhang, X., Azhar, S., Nadeem, A. and Khalfan, M. (2018), "Using Building Information Modelling to achieve Lean principles by improving efficiency of work teams", International Journal of Construction Management, Taylor \& Francis, Vol. 18 No. 4, pp. 293-300.

Zirar, A., Trusson, C. and Choudhary, A. (2020), "Towards a high-performance HR bundle process for lean service operations", International Journal of Quality \& Reliability Management. 